\title{
Barnekreft og fertilitet
}

I Norge fikk i 2008147 barn under 15 år en kreftdiagnose (1). Blant pasienter i denne aldersgruppen er leukemi, hjernesvulster og malignt lymfom de hyppigste diagnoser. Femårsoverlevelse for barn i Norge er i dag på $80 \%$ (2).

Ved siden av å helbrede disse pasientene er det et mål at de skal kunne leve mest mulig som andre unge personer med henblikk på yrke, partnerskap og mulighet til å bli foreldre. Utenlandske studier har imidlertid vist at minst halvparten av overlevende barnekreftpasienter har fysiske og/eller mentale senfølger knyttet til kreftsykdommen eller behandlingen $(3,4)$.

I en amerikansk studie rapporterte $45 \%$ av mennene og $20 \%$ av kvinnene infertilitet etter kreftbehandling i barnealderen $(5,6)$. Kjønnsforskjellen blir bekreftet $i$ en pågående norsk studie der man har koblet Kreftregisterets barnekreftregister med informasjon fra Medisinsk fødselsregister: Personer med kreftdiagnose før 15-årsalderen har en lavere fødselsrate sammenliknet med kontrollpersoner uten kreft som barn. Andelen barnløse blant barnekreftoverlevende er større hos menn enn hos kvinner.

I dette nummer av Tidsskriftet påpeker Stensvold og medarbeidere risikoen for nedsatt fertilitet eller infertilitet etter kreft i barne- og ungdomsalderen og hvilke tiltak som i dag er aktuelle for å redusere denne risikoen $(7,8)$. Fertilitetsbevarende tiltak blant kreftpasienter har vært brukt i Norge i 30 år. Uten å redusere helbredelsessjansene har strålebehandling, kirurgiske inngrep og cellegiftbehandling vært modifisert hos barn og unge pasienter for å bevare deres forplantningsevne, for eksempel hos pasienter med testikkelkreft, malignt lymfom og sarkom. Siden 1990 har unge menn fått tilbud om nedfrysning av sæd før kreftbehandlingens start ved de fleste onkologiske avdelinger.

Fertilitetsbevarende tiltak hos barn byr imidlertid på større problemer enn hos unge voksne. Foreldrene må involveres i samtalene og være med på å ta den endelige avgjørelsen. For en gutt blir spørsmålet ofte om han har sædproduksjon i det hele tatt, og om han er i stand til å avgi en sædprøve. Stensvold og medarbeidere viser til at biologisk materiale for nedfrysning kan innhentes ved elektroejakulasjon, penisvibrasjon og eventuelt ved nedfrysning av testikkelvev (foreløpig ikke tillatt i Norge). Slike tiltak krever en høy grad av psykologisk modenhet hos den unge kreftpasienten. For eksempel har man i Norge forsøkt penisvibrasjon hos mindre enn ti gutter, og i de få forsøkene har problematikken i slike prosedyrer blitt understreket. Det er viktig at pasientene og foreldrene er klar over at disse metodene, spesielt nedfrysning av testikkelvev, fortsatt er eksperimentelle og at man ikke kan love suksess for den enkelte pasienten.

Situasjonen er enda mer komplisert hos unge jenter. Nedfrysning av ovarialvev for senere autotransplantasjon er et tilbud i Norge i dag, men må anses som høyst eksperimentelt. Inntil nå er det $i$ hele verden bare registrert 20 svangerskap med utgangspunkt i nedfryst ovarialvev. I Norge er det ikke født barn etter slike tiltak, men ovarialvev er blitt fryst ned for ca. 100 pasienter, og ti av disse har vært yngre enn 15 år.

Muligheten til å få barn er utvilsomt en sentral del av god livskvalitet for den helbredede barnekreftpasienten. Fertilitetsbevarende tiltak bør derfor alltid vurderes før oppstart av behandling av en ung pasient. Funn hos voksne kreftpasienter tyder ikke på at svangerskap etter en kreftdiagnose øker morens risiko for kreftrelatert død
$(9,10)$. Det å ta opp fremtidig fertilitet med en ung kreftpasient og hans/hennes pårørende har i tillegg stor psykologisk betydning: Indirekte får pasienten informasjon om at legen tror på et «liv etter kreften», dvs. på helbredelse.

Resultater av en pågående studie blant norske kreftoverlevende viser at 43 av 45 kvinner med ønske om barn ble gravide trass i behandling for malignt lymfom i barnealder. Sammenliknbare tall for menn var 21 av $33(64 \%)$. Det er kreftlegenes ansvar å kjenne til risikoen for infertilitet ved behandling av kreft hos barn. Denne risikoen må balanseres mot barnets alder, modenhet og de til dels krevende, eksperimentelle tiltakene som Stensvold og medarbeidere beskriver. Allerede i dag har slike tiltak vist seg nyttige for enkeltpasienter. Fremtidig forskning vil vise hvorvidt slike tiltak øker muligheten for foreldreskap hos overlevende etter kreft på gruppenivå, og hvem som har mest nytte av tilbudet. Erfaringene fra norske voksne testikkelkreftpasienter er at kun $7 \%$ av menn som har overlevd kreft har etter en observasjonsperiode på 20 år brukt sin nedfryste sæd (11).

\section{Sophie D. Fosså \\ sdf@ous-hf.no \\ Det medisinske fakultet \\ Universitetet i Oslo}

Hanne M. Hamre

Oslo universitetssykehus, Radiumhospitalet

Sophie D. Fosså (f. 1941) er overlege ved Oslo universitetssykehus, Radiumhospitalet og professor ved Universitetet i Oslo.

Oppgitte interessekonflikter: Universitetet i Oslo har mottatt konsultasjonshonorar fra Sanofi-Aventis. Sophie D. Fosså har mottatt honorar for foredrag fra firmaene Novartis, Sanofi-Aventis og Amgen.

Hanne M. Hamre (f. 1974) er onkolog og stipendiat ved Oslo universitetssykehus, Radiumhospitalet.

Ingen oppgitte interessekonflikter.

\section{Litteratu}

1. Cancer in Norway 2008 - Cancer incidence, mortality, survival and prevalence in Norway. Oslo: Kreftregisteret, 2009

Brenner H. Steliarova-Foucher E, Arndt V. Up-to-date monitoring of childhood cancer long-term survival in Europe. Ann Oncol 2007; 9: 1561-8.

3. Oeffinger KC, Mertens AC, Sklar CA et al. Chronic health conditions in adult survivors of childhood cancer. N Engl J Med 2006; 355: 1572-82.

4. Geenen MM, Cardous-Ubbink MC, Kremer LC et al. Medical assessment of adverse health outcomes in long-term survivors of childhood cancer. JAMA 2007; 297: 2705-15

5. Green DM, Kawashima T, Stovall M et al. Fertility of female survivors of childhood cancer: A report from the childhood cancer survivor study. J Clin Oncol 2009: 27: 2677-85

6. Green DM, Kawashima T, Stovall M, et al. Fertility of male survivors of childhood cancer: A report from the childhood cancer survivor study. J Clin Oncol 2010; 28: $332-9$.

7. Stensvold E, Magelssen H, Oskam IC. Fertilitetsbevarende tiltak hos gutter og unge menn med kreft. Tidsskr Nor Legeforen 2011; 131: 1433-5.

8. Stensvold E, Magelssen H, Oskam IC. Fertilitetsbevarende tiltak hos jenter og unge kvinner med kreft. Tidsskr Nor Legeforen 2011; 131: 1429-32.

9. Stensheim H, Møller B, van Dijk T et al. Cause-specific survival for women diagnosed with cancer during pregnancy or lactation: a registry-based cohort study. J Clin Oncol 2009: 27: 45-51.

10. Magelssen H, Melve KK, Skjaerven R et al. Parenthood probability and pregnancy outcome in patients with a cancer diagnosis during adolescence and young adulthood. Hum Reprod 2008; 23: 178-86.

11. Magelssen $H$, Haugen TB, von Düring V et al. Twenty years experience with semen cryopreservation in testicular cancer patients: who needs it? Eur Urol 2005; 48: 779-85. 